\title{
ANALISIS PEMERINGKATAN SUKUK: PERSPEKTIF KEUANGAN
}

\author{
Wahyu Pramesti \\ IAIN Surakarta \\ wahyupramesti@gmail.com
}

\begin{abstract}
The aims of this study is to analysed sukuk rating from financial perspective. Financial perspective used in this research is profitability, likuidity, and firm size. Sample used in this study is sukuk listed in BEI during 2010 - 2015. Used multiple regression to analysis model both partially and simultanly. Used financial performance to analyse sukuk rating. The result of this study show that profitability, likuidity, and firm size have significant effect to sukuk rating.
\end{abstract}

Keywords: Sukuk; Sukuk Rating; Financial Performance

\section{A. Pendahuluan}

Salah satu instrument pasar modal syariah adalah instrumen investasi syariah berupa sukuk. Sukuk di Indonesia pertama kali diterbitkan oleh PT. Indosat Tbk pada tahun 2002 yang disusul penerbitan sukuk oleh emiten lain. Jumlah penerbitan sukuk dari tahun ke tahun semakin berkembang, baik sukuk korporasi maupun sukuk yang diterbitkan oleh negara.

Seiring dengan pertumbuhan jumlah penerbitan sukuk, semakin banyak pula jumlah pilihan investor untuk berinvestasi pada sukuk. Hal tersebut membuat investor perlu mempertimbangan beberapa hal sebelum memutuskan berinvestasi pada sukuk. Salah satu hal yang menjadi bahan pertimbangan adalah rating sukuk. Peringkat sukuk menggambarkan seberapa rendah risiko kerugian yang mungkin dihadapi oleh investor. Semakin baik peringkat 
sukuk menandakan bahwa emiten sukuk memiliki risiko gagal bayar yang rendah.

\section{Gambar. 1}

\section{Grafik Perkembangan Sukuk di Indonesia Periode 2010-2015}

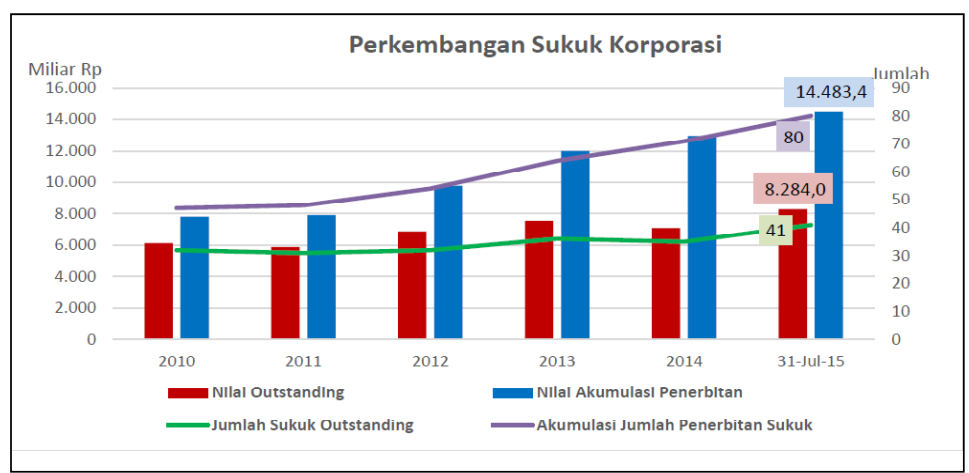

Sumber: www.ojk.go.id

Penelitian mengenai peringkat sukuk di Indonesia masih tergolong belum terlalu banyak. Dari beberapa penelitian yang telah dilakukan sebelumnya oleh Purwaningsih (2013), Melis (2015), Afiani (2013), Arisanti et al (2014), Arundina dan Omar (2009), Sudaryanti, Mahfudz, and Wulandari (2011) menunjukkan hasil yang beragam. Telaah yang telah dilakukan oleh peneliti sebelumnya meninjau baik dari aspek keuangan maupun non keuangan. Keberagaman hasil penelitian sebelumnya itulah yang mendorong peneliti untuk meneliti mengenai pemeringkatan sukuk dari perspektif keuangan.

\section{B. Tinjauan Pustaka}

Sukuk didefinisikan sebagai representasi kepemilikan yang profesional dari aset untuk jangka waktu tertentu dengan risiko serta imbalan yang dikaitkan dengan aliran kas yang memiliki underlying asset yang berada di tangan investor (Iqbal \& Mirakhor, 2011). Sedangkan berdasarkan fatwa MUI (2002) mendefinisikan obligasi syariah sebagai surat berharga jangka panjang berdasarkan prinsip syariah yang dikeluarkan Emiten kepada pemegang Obligasi Syariah yang mewajibkan Emiten untuk membayar pendapatan kepada pemegang Obligasi Syariah berupa bagi hasil/ margin/fee serta membayar kembali dana Obligasi Syariah pada saat jatuh tempo. 
Penelitian sebelumnya mengenai peringkat sukuk banyak mengupas tentang faktor-faktor yang mempengaruhi pemeringkatan sukuk baik dari sisi keuangan maupun non keuangan (Afiani, 2013; Arisanti et al., 2014; Arundina \& Omar, 2009; Arundina, Omar, \& Kartiwi, 2015; Elhaj, Muhamed, \& Ramli, 2015; Fachrurrozie \& Jayanto, 2014; Melis, 2015; Purwaningsih, 2013; Sudaryanti et al., 2011; Zakaria, Isa, \& Abidin, 2012). Namun, secara spesifik belum diketemukan kajian yang mengkaji tentang pemeringkatan sukuk berasal dari perspektif keuangan.

Sukuk yang beredar di pasar modal Indonesia harus diberi rating/peringkat. Terdapat 6 lembaga pemeringkat efek yang diakui oleh Bank Indonesia yakni Fitch Ratings, Moody's Investor Service, Standard and Poor's, PT. Fitch Rating Indonesia, PT. ICRA Indonesia, dan PT. Pemeringkat Efek Indonesia. Berikut adalah salah satu peringkat sukuk menurut Pefindo.

\section{Gambar. 2}

\section{Standar Peringkat Sukuk Menurut Pefindo}

\begin{tabular}{|c|c|}
\hline Symbol & Long Term Syariah Based Financing Instruments \\
\hline $\operatorname{IdAAA}($ sy) & $\begin{array}{l}\text { A syariah based finanding instrument rated „AAA in has the highest rating assigned by PEFINDO. The issuer's } \\
\text { capocity to meet it long-term financial commitments under the sariah financing wontract, relative to other } \\
\text { Indonesian issues, is superior. }\end{array}$ \\
\hline $\operatorname{IdAA}(s y)$ & 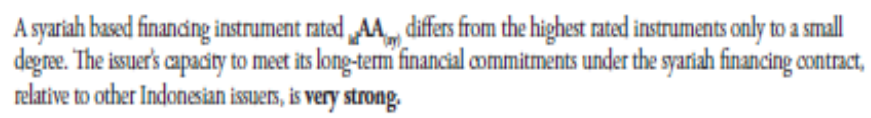 \\
\hline $\mathrm{Id} A(y)$ & 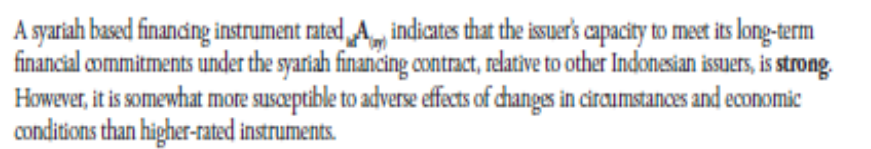 \\
\hline $\mathrm{IdBBB}(s y)$ & 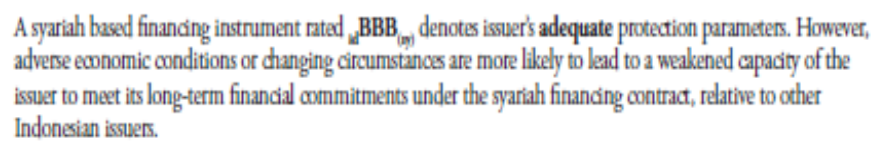 \\
\hline $\mathrm{AdBB}(\boldsymbol{y})$ & 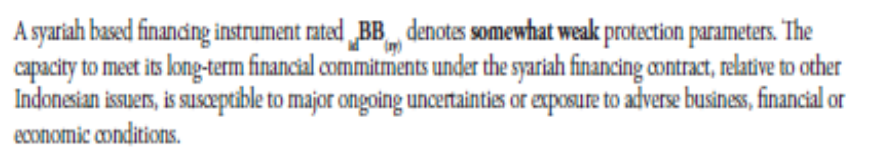 \\
\hline
\end{tabular}




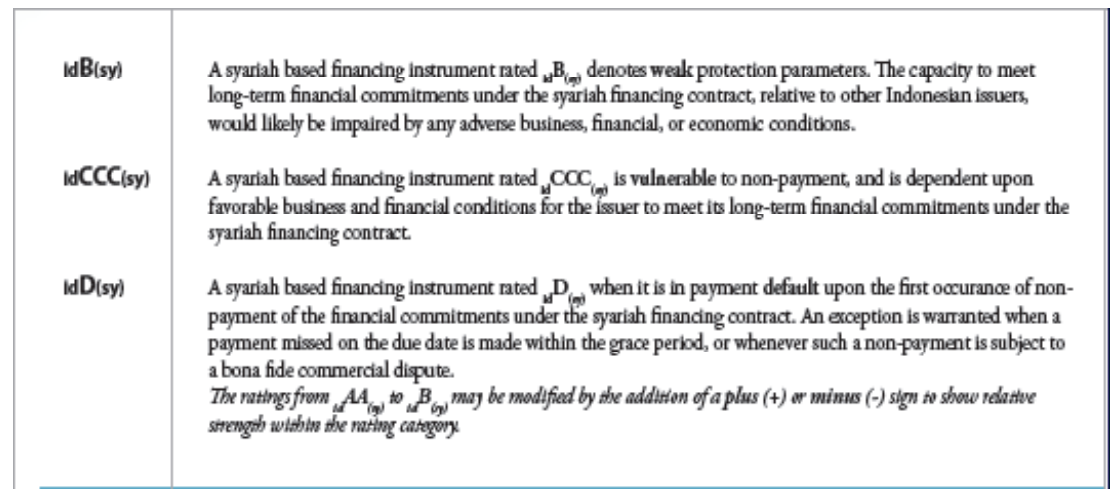

Sumber: www.pefindo.com

Menurut Hanafi dan Halim (2014), rasio rofitabilitas mengukur kemampuan perusahaan menghasilkan keuntungan pada tingkat penjualan, aset, dan modal saham tertentu. Sehingga profitabilitas menggambarkan efektivitas perusahaan beroperasi sehingga memberikan keuntungan. Hal tersebut berarti semakin tinggi profitabilitas perusahaan, semakin efektiv perusahaan beroperasi.

Salah satu rasio profitabilitas yang sering digunakan adalah Return on Asset (ROA). Menurut Hanafi dan Halim (2014), ROA digunakan untuk mengukur kemampuan perusahaan menghasilkan laba bersih berdasarkan tingkat aset tertentu. ROA digunakan sebagai proksi profitabilitas dalam penelitian ini.

Berdasarkan hasil penelitian Afiani (2013) menunjukkan bahwa terdapat pengaruh variabel profitabilitas terhadap peringkat sukuk. Sedangkan pada hasil penelitian Arundina dan Omar (2009) menunjukkan bahwa ROA tidak memiliki hubungan signifikan terhadap peringkat sukuk. Hasil penelitian Melis (2015) menunjukkan bahwa rasio profitabilitas tidak berpengaruh terhadap rating sukuk. Dari uraian tersebut, maka hipotesis yang dapat diajukan dari penelitian ini adalah:

$\begin{aligned} \mathrm{H} 1= & \text { Terdapat pengaruh rasio profitabilitas (ROA) terhadap } \\ & \text { peringkat sukuk. } \\ & \text { Menurut Hanafi dan } \operatorname{Halim}(2014) \text {, rasio likuiditas mengukur }\end{aligned}$ kemampuan likuiditas jangka pendek perusahaan dengan melihat aset lancar perusahaan relatif terhadap utang lancarnya. Semakin 
tinggi rasio likuiditas suatu perusahaan berarti semakin baik pula kemampuan perusahaan untuk memenuhi kewajiban jangka pendeknya dan semakin kuat kondisi keuangan yang dimiliki perusahaan. Salah satu alat ukur likuiditas adalah rasio lancar (current ratio). Current Ratio digunakan sebagai proksi dalam penelitian ini.

Berdasarkan hasil penelitian dari Afiani (2013), menyatakan bahwa terdapat pengaruh variabel likuiditas terhadap peringkat sukuk. Dukungan hasil penelitian tersebut juga dikuatkan oleh hasil penelitian Arisanti et al (2014) yang menunjukkan bahwa variabel likuiditas berpengaruh signifikan terhadap prediksi peringkat obligasi syariah. Hal serupa juga mendapat dukungan dari hasil penelitian Melis (2015) yang menunjukkan bahwa rasio likuiditas berpengaruh positif terhadap rating sukuk. Namun berdasarkan hasil penelitian dari Purwaningsih (2013) diperoleh bukti empiris bahwa likuiditas tidak berpengaruh terhadap rangking sukuk. Dari uraian tersebut, maka hipotesis yang dapat diajukan dari penelitian ini adalah:

$\mathrm{H} 2=$ Terdapat pengaruh rasio likuiditas (current ratio) terhadap peringkat sukuk.

Ukuran perusahaan merupakan suatu skala untuk mengukur dan menggolongkan besar kecilnya perusahaaan. Ukuran perusahaan secara umum dibeberapa literatur diukur dengan beberapa ukuran yang berbeda diantaranya adalah total aset (Cameran, 2005; Castro, Peleias, \& Silva, 2015; Hassan \& Naser, 2013; Inchausti, 1997; Naser \& Hassan, 2016; Othman, Thani, \& Ghani, 2009; Rusmanto \& Waworuntu, 2015; ulHaq \& Leghari, 2015; Vermeer, Raghunandan, \& Forgione, 2009; Younas, Velte, \& Ashfaq, 2014). Ukuran perusahaan selanjutnya yang digunakan adalah jumlah pegawai (Fleischer \& Goettsche, 2012; Naser \& Nuseibeh, 2008). Terdapat juga beberapa penelitian yang mengukur ukuran perusahaan menggunakan total penjualan (Naser, Al-Khatib, \& Karbhari, 2002; Rouf, 2011).

Penelitian yang dilakukan oleh Arundina dan Omar (2009) menunjukkan hasil bahwa variabel total aset memiliki hubungan signifikan dengan peringkat sukuk. Dukungan penelitian tersebut 
diperoleh dari Sudaryanti et al. (2011) menunjukkan bahwa determinan peringkat sukuk adalah ukuran perusahaan. Akan tetapi hal yang berkebalikan ditunjukkan dari hasi penelitian Arisanti et al (2014) yang menyebutkan bahwa variabel size tidak berpengaruh signifikan terhadap prediksi peringkat obligasi syariah. Dari uraian tersebut, maka hipotesis yang dapat diajukan dari penelitian ini adalah:

H3 = Terdapat pengaruh ukuran perusahaan (total aset) terhadap peringkat sukuk.

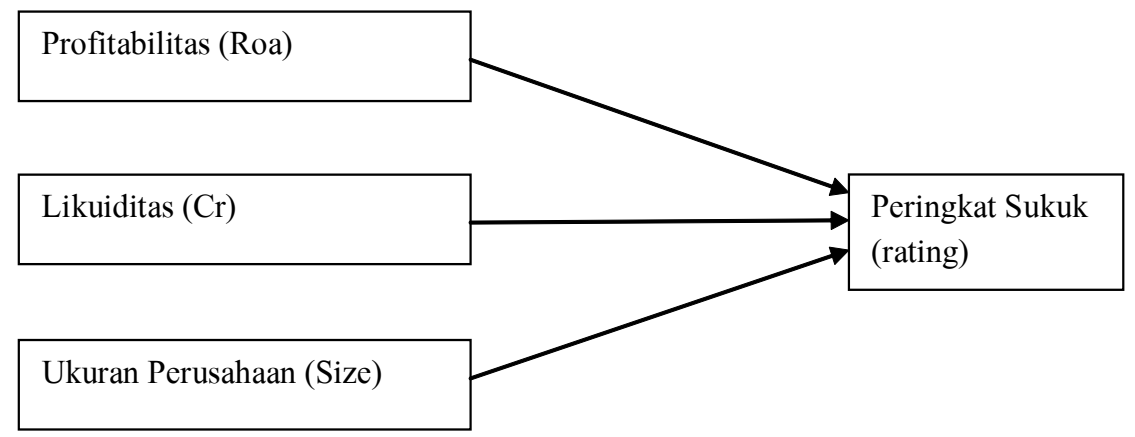

\section{Metode Penelitian}

Populasi yang digunakan dalam penelitian ini adalah seluruh sukuk yang terdaftar pada Bursa Efek Indonesia (BEI) periode 2010 - 2015. Sampel dipilih dengan kriteria:

1. Sukuk korporasi yang terdaftar di Bursa Efek Indonesia

2. Lembaga pemeringkat sukuk oleh PT Pefindo

3. Sukuk beredar selama periode pengamatan 2010 - 2015

4. Terdapat laporan keuangan emiten sukuk selama periode pengamatan

Penelitian ini menggunakan analisis regresi berganda. Analisis regresi linear berganda digunakan untuk mengukur pengaruh antara lebih dari satu variabel independen terhadap satu variabel dependen (Ghozali, 2016). Dalam (Indriantoro \& Supomo, 2002) dijelaskan bahwa "analisis regresi berganda pada dasarnya merupakan ekstensi dari metode regresi dalam analisis bivariate yang umumnya digunakan untuk menguji pengaruh dua atau lebih variabel independen terhadap variabel dependen dengan skala 
pengukuran interval atau rasio dalam suatu persamaan linear". Terdapat 2 tahap dalam melakukan analisis data:

\section{Uji Asumsi Klasik}

Uji asumsi klasik digunakan untuk memenuhi sifat estimasi regresi sebelum dilakukan pengujian hipotesis. Dalam penelitian ini menggunakan 4 uji asumsi klasik, yakni uji normalitas, uji multikolinieritas, uji autokorelasi, dan uji heteroskedastisitas.

\section{Uji Hipotesis}

Teknik analisis data menggunakan analisis regresi untuk menguji kekuatan hubungan antara variabel independen terhadap variabel dependen. Ghozali (2016) menjelaskan bahwa dalam analisis regresi tidak hanya menjelaskan hubungan antara dua variabel atau lebih namun juga menunjukkan arah hubungan antara variabel dependen dengan variabel independen.

Persamaan regresi:

$$
\text { Rating }=\beta_{0}+\beta_{1} \text { Roa }+\beta_{2} \mathrm{Cr}+\beta_{3} \operatorname{Size}+\varepsilon
$$

Keterangan:

$\begin{array}{ll}\text { Rating } & \text { : peringkat sukuk } \\ \text { Roa } & \text { : profitabilitas perusahaan } \\ \mathrm{Cr} & \text { : likuiditas perusahaan } \\ \text { Size } & \text { : ukuran perusahaan } \\ \varepsilon & \text { : error }\end{array}$

\section{D.Hasil Dan Pembahasan}

\section{Isi Hasil dan Pembahasan}

\section{a. Uji Asumsi Klasik}

1) Uji Normalitas

Uji normalitas bertujuan untuk menguji apakah dalam model regresi, variabel pengganggu atau residual memiliki distribusi normal (Ghozali, 2016). Untuk melakukan uji normalitas dapat menggunakan uji statistik non parametrik Kolmogorov-Smirnov (K-S). 
Tabel. 3

Uji Normalitas

\begin{tabular}{ccccc}
\hline Variabel & $\begin{array}{c}\text { Kolmogorof } \\
\text { smirnov }\end{array}$ & $\begin{array}{c}\text { Signifikansi } \\
\text { (2-tailed) }\end{array}$ & Kriteria & Hasil \\
\hline $\begin{array}{c}\text { Unstandardised } \\
\text { resudial }\end{array}$ & 0,082 & 2,00 & $\begin{array}{c}\text { Prob } \\
>0,05\end{array}$ & $\begin{array}{c}\text { Data } \\
\text { residual } \\
\text { terdistribusi } \\
\text { normal }\end{array}$ \\
\hline
\end{tabular}

Sumber: SPSS diolah

Berdasarkan hasil tabel di atas, nilai Kolmogorov-Smirnov diatas 5\% sehingga data residual dalam variabel penelitian berdistribusi normal.

2) Uji Multikolinieritas

Uji multikolinearitas bertujuan untuk menguji apakah model regresi ditemukan adanya korelasi antar variabel independen (Ghozali, 2016). Untuk mendeteksi ada tidaknya gejala multikolinearitas antar variabel independen digunakan uji variance inflation factor (VIF). Jika VIF yang dihasilkan diantara 1-10 maka tidak terjadi multikolinearitas.

Tabel. 4

Uji Multikolinieritas

\begin{tabular}{ccc}
\hline Variabel & $\begin{array}{c}\text { Variance Inflation } \\
\text { Factor }(\text { VIF })\end{array}$ & Keterangan \\
\hline Roa & 1,061 & Tidak terdapat multikolinieritas \\
Cr & 1,529 & Tidak terdapat multikolinieritas \\
Size & 1,467 & Tidak terdapat multikolinieritas \\
\hline
\end{tabular}

Sumber: SPSS diolah

Dari tabel di atas, masing-masing variabel independen memiliki nilai $\mathrm{VIF}<10$, sehingga dapat disimpilkan bahwa semua variabel tidak terdapat multikolinieritas.

3) Uji Autokorelasi

Autokorelasi adalah korelasi antara anggota-anggota serangkaian observasi yang diurutkan menurut waktu (seperti dalam time series) atau ruang (Ghozali, 2016). Untuk mendeteksi adanya gejala autokorelasi digunakan uji durbin watson. 
Tabel. 5

Uji Autokorelasi

\begin{tabular}{cccccc}
\hline Model & R & R square & $\begin{array}{c}\text { Adj R } \\
\text { Square }\end{array}$ & $\begin{array}{c}\text { Std Error of } \\
\text { Estimate }\end{array}$ & $\begin{array}{c}\text { Durbin } \\
\text { Watson }\end{array}$ \\
\hline 1 & .790 & .624 & .595 & .08738 & 2,687 \\
\hline
\end{tabular}

Sumber: SPSS diolah

Dari tabel di atas, nilai durbin watson sebesar 2,687 kurang dari 4 sehingga dapat disimpulkan bahwa tidak terdapat autokorelasi.

4) Uji Heteroskedastisitas

Heteroskedastisitas adalah terjadinya ketidaksamaan dari residual satu pengamatan ke pengamatan yang lain (Ghozali, 2016). Alat yang digunakan untuk mendeteksi adanya heteroskedastisitas dilakukan dengan uji glejser. Uji Glejser mengusulkan untuk meregresi nilai absolut residual terhadap variabel independen. Berikut ini disajikan hasil uji heteroskedastisitas kedua variabel independen yaitu:

Tabel. 6

Uji Heteroskedastisitas

\begin{tabular}{ccl}
\hline Variabel & Signifikansi & \multicolumn{1}{c}{ Keterangan } \\
Roa & 0.067 & Terjadi heteroskedastisitas \\
\hline $\mathrm{Cr}$ & 0.239 & Tidak terjadi heteroskedastisitas \\
Size & 0.051 & Tidak terjadi heteroskedastisitas \\
\hline
\end{tabular}

Sumber: SPSS diolah

Kriteria tidak ada heteroskedastisitas jika nilai signifikansi variabel independen $>0,05$. Sehingga dapat disimpulkan bahwa tidak terdapat heteroskedastisitas.

\section{Uji Hipotesis}

Dalam pengujian penelitian ini, hipotesis diuji menggunakan regresi berganda. Analisis regresi berganda untuk mengetahui bagaimana variabel dependen berhubungan dengan dua atau lebih variabel independen (Ghozali, 2016). Dalam penelitian ini variabel dependen adalah peringkat sukuk sedangkan variabel dependennya adalah profitabilitas perusahaan, likuiditas perusahaaan, dan ukuran perusahaan. 


\section{Uji Koefisien Determinasi (R2)}

Koefesien determinasi $\left(R^{2}\right)$ pada intinya mengukur seberapa jauh kemampuan model dalam menerangkan variasi variabel dependen (Ghozali, 2016). Nilai koefesien determinasi berkisar antara $0 \leq R^{2} \leq 1$. Bila nilai $R^{2}$ semakin mendekati satu maka variabel independen yang ada semakin besar dalam menjelaskan variabel dependen, tetapi bilai nilai $\mathrm{R}^{2}$ mendekati nol maka variabel independen semakin kecil dalam menjelaskan variabel dependen.

\section{Tabel. 7}

Uji Koefisien Determinasi

\begin{tabular}{ccc}
\hline $\mathrm{R}$ & $\mathrm{R}$ Square & Adjusted R Square \\
\hline, $790^{\mathrm{a}}$ &, 624 &, 595 \\
\hline
\end{tabular}

Sumber: SPSS diolah

Dari nilai yang ditunjukkan pada tabel di atas, nilai Adjusted $\mathrm{R}^{2}$ sebesar 0,595. Dengan demikian dapat disimpulkan bahwa variabel independen dapat menjelaskan sebesar 59,5\% atas variabel dependen, sedangkan sisanya sebesar 40,5\% dijelaskan oleh faktur lain di luar model persamaan regresi.

\section{Uji Ketepatan Model}

Pengujian ketepatan model pada persamaan regresi dilakukan dengan menggunakan uji F. Uji F dilakukan untuk mengetahui apakah variabel independen secara bersama-sama atau simultan mempengaruhi variabel dependen (Ghozali, 2016). Syarat agar model tersebut dapat digunakan untuk prediksi adalah dengan melihat probabilitas dari uji tersebut, jika hasil pengujian menunjukkan angka probabilitas kurang dari 5\% maka model tersebut dapat digunakan untuk estimasi.

Tabel. 8

Hasil Uji F

\begin{tabular}{cccccc}
\hline Model & $\begin{array}{c}\text { Sum of } \\
\text { Squares }\end{array}$ & Df & $\begin{array}{c}\text { Mean } \\
\text { Square }\end{array}$ & F & Sig \\
\hline Regression &, 482 & 3 &, 161 & 21,058 &, 000 \\
Residual &, 290 & 38 &, 008 & & \\
Total &, 772 & 41 & & & \\
\hline
\end{tabular}

Sumber: SPSS diolah 
Berdasarkan pengujian regresi di atas nilai $\mathrm{F}$ hitung untuk peringkat sukuk sebesar 21,058 dengan tingkat signifikansi 0,000. Prasyarat probabilitas agar hipotesis dapat diterima adalah 5\%. Nilai probabilitas hasil pengujian kurang dari 5\% sehingga model regresi tersebut dapat diterima untuk memprediksi ketepatan model profitabilitas, likuiditas, dan ukuran perusahaan terhadap peringkat sukuk.

\section{Uji Regresi}

Model regresi, keandalannya sebagai alat estimasi sangat ditentukan oleh signifikansi parameter-parameter dalam model yaitu koefisien regresi. Uji signifikansi dilakukan dengan uji t. Uji $\mathrm{t}$ digunakan untuk menguji signifikansi koefisien regresi secara parsial dari variabel independennya (Ghozali, 2016).

Tabel. 9

Hasil Uji $\mathrm{t}$

\begin{tabular}{cccccc}
\hline Model & \multicolumn{2}{c}{$\begin{array}{c}\text { Unstandardized } \\
\text { Coefficients }\end{array}$} & $\begin{array}{c}\text { Standardized } \\
\text { Coefficients }\end{array}$ & T & Sig. \\
\cline { 2 - 4 } & B & Std Error & Beta & & \\
(Constant) & 1,261 &, 109 & & 11,604 &, 000 \\
Roa &, 100 &, 046 &, 225 & 2,197 &, 034 \\
Cr &,- 566 &, 082 &,- 850 & $-6,910$ &, 000 \\
Size &, 497 &, 070 &, 856 & 7,106 &, 000 \\
\hline
\end{tabular}

Sumber: SPSS diolah

Dari hasil uji t, dapat dirumuskan persamaan regresi untuk hubungan antara variabel independen dengan variabel dependen sebagai berikut:

$$
\text { Rating = 1,261 + 0,1 Roa - 0,566 Cr + 0,497 Size + } \varepsilon
$$

Di bawah ini disajikan tabel uji hipotesis untuk hipotesis yang telah dirumuskan

Tabel. 10

Hasil Uji Hipotesis

\begin{tabular}{ccccc}
\hline Variabel & B & Sig & Keterangan & Arah Hubungan \\
\hline Roa &, 100 &, 034 & $\mathrm{H}_{1}$ Diterima & Positif \\
$\mathrm{Cr}$ &,- 566 &, 000 & $\mathrm{H}_{2}$ Diterima & Negatif \\
Size &, 497 &, 000 & $\mathrm{H}_{3}$ Diterima & Positif \\
\hline
\end{tabular}


Dari tabel di atas dapat diketahui bahwa:

1) Variabel Roa memiliki nilai $\beta 0,100$, nilai tersebut menunjukkan bahwa arah hubungan antara Roa dengan peringkat sukuk memiliki arah hubungan positif dengan nilai probabilitas 0,034. Kriteria penerimaan hipotesis jika nilai probabilitas kurang dari 0,05, sehingga hipotesis pertama yang menyatakan bahwa terdapat pengaruh antara profitabilitas perusahaan dengan peringkat sukuk diterima.

2) Variabel $\mathrm{Cr}$ memiliki nilai $\beta-0,566$, nilai tersebut menunjukkan bahwa arah hubungan antara $\mathrm{Cr}$ dengan peringkat sukuk memiliki arah hubungan negatif dengan nilai probabilitas 0,000 . Kriteria penerimaan hipotesis jika nilai probabilitas kurang dari 0,05 , sehingga hipotesis kedua yang menyatakan bahwa terdapat pengaruh antara likuiditas perusahaan dengan peringkat sukuk diterima.

3) Variabel Size memiliki nilai $\beta 0,479$, nilai tersebut menunjukkan bahwa arah hubungan antara size dengan peringkat sukuk memiliki arah hubungan positif dengan nilai probabilitas 0,000. Kriteria penerimaan hipotesis jika nilai probabilitas kurang dari 0,05, sehingga hipotesis ketiga yang menyatakan bahwa terdapat pengaruh antara ukuran perusahaan dengan peringkat sukuk diterima.

\section{Pembahasan Hasil Pengujian}

Penelitian ini berusaha untuk menganalisis faktor yang mempengaruhi pemeringkatan sukuk dilihat dari perspektif keuangan. Pemeringkatan sukuk diperlukan bagi investor dalam penentuan keputusan investasinya. Analisis faktor yang mempengaruhi pemeringkatan sukuk berusaha dilihat dari perspektif keuangan.

Penelitian terdahulu telah dilakukan untuk menganalisis faktor yang mempengaruhi pemeringkatan sukuk baik dari segi keuangan maupun non keuangan. Akan tetapi penulis berusaha mengkhaskan penelitian ini dengan berfokus pada perspektif keuangan. Perspektif keuangan dinilai menjadi hal yang penting dalam dunia ekonomi, dalam hal ini adalah investasi. 
Perspektif keuangan yang dimaksudkan dalam penelitian ini adalah profitabilitas perusahaan, likuiditas perusahaan, dan ukuran perusahaan. Profitabilitas perusahaan yang diukur dengan ROA (return on assets) berusaha menjelaskan seberapa besar tingkat pengembalian yang dapat diberikan atas hasil aktivitas utama perusahaan dengan jumlah aset tertentu yang dimiliki perusahaan. Semakin tinggi nilai ROA menandakan bahwa manajemen dapat bertindak efektif dan efisien dalam melaksanakan aktivitas utama perusahaan dengan memanfaatkan sumber daya yang ada di perusahaan. Perusahaan yang mampu bertindak secara efektif dan efisien diharapkan juga mampu memenuhi segala kewajibannya sehingga memungkinkan untuk mendapatkan peringkat atas kewajibannya dengan baik.

Hasil pengujian hipotesis pertama menunjukkan bahwa variabel roa berpengaruh positif terhadap rating. Berdasarkan hasil tersebut dapat diketahui bahwa profitabilitas perusahaan berpengaruh positif terhadap peringkat sukuk. Hal tersebut menunjukkan bahwa ketika profitabilitas perusahaan semakin baik maka peringkat sukuk juga akan semakin baik.

Likuiditas perusahaan yang diukur dengan CR (current ratio) berusaha menjelaskan tingkat kemampuan perusahaan dalam memenuhi kewajiban jangka pendeknya dengan menggunakan aset lancar yang dimiliki perusahaan. Nilai CR yang tinggi mengindikasikan bahwa semakin baik perusahaan dalam memenuhi kewajiban jangka pendeknya menggunakan aset lancarnya. Dengan nilai CR yang baik memungkinkan mendapatkan peringkat atas kewajibannya dengan baik.

Hasil pengujian hipotesis kedua menunjukkan bahwa variabel cr berpengaruh negatif terhadap rating. Berdasarkan hasil tersebut dapat diketahui bahwa likuiditas perusahaan berpengaruh negatif terhadap peringkat sukuk. Hal tersebut menunjukkan bahwa likuiditas perusahaan mempengaruhi peringkat sukuk.

Ukuran perusahaan diukur dengan menggunakan total aset. Perusahaan yang memiliki nilai total aset besar memungkinkan untuk memiliki kemampuan memenuhi kewajibannya dengan menggunakan aset yang dimiliki perusahaan. Hal tersebut 
menandakan bahwa semakin besar nilai aset perusahaan memungkinkan semakin baik pula dalam pemenuhan kewajibannya.

Hasil pengujian hipotesis ketiga menunjukan bahwa variabel size berpengaruh positif terhadap rating. Berdasarkan hasil tersebut dapat diketahui bahwa ukuran perusahaan berpengaruh positif terhadap peringkat sukuk. Hal tersebut menunjukkan bahwa ketika ukuran perusahaan semakin besar maka peringkat sukuk juga akan semakin baik.

\section{E. Simpulan}

Penelitian ini mengidentifikasi 3 faktor yang mempengaruhi peringat sukuk dari perspektif keuangan yakni profitabilitas perusahaan, likuiditas perusahaan, dan ukuran perusahaan. Dari hasil pembahasan dapat disimpulkan bahwa profitabilitas, likuiditas, dan ukuran perusahan mempengaruhi pemeringkatan sukuk. 


\section{DAFTAR PUSTAKA}

Afiani, D. (2013). Pengaruh Likuiditas, Produktivitas, Profitabilitas, dan Laverage Terhadap Peringkat Sukuk. Accounting Analysis Journal, 2(1).

Arisanti, I., Fadah, I., \& Puspitasari, N. (2014). Analisis Faktor Keuangan dan Non Keuangan yang Mempengaruhi Prediksi Peringkat Obligasi Syariah. Jurnal Ekonomi Akuntansi dan Manajemen, 13(2).

Arundina, T., \& Omar, M. A. (2009). Determinant of Sukuk Ratings. Bulletin of Monetary Economics and Banking, 12(1), 97 - 113.

Arundina, T., Omar, M. A., \& Kartiwi, M. (2015). The predictive accuracy of Sukuk ratings; Multinomial Logistic and Neural Network inferences. Pacific-Basin Finance Journal, 34, 273-292. doi: https://doi.org/10.1016/j.pacfin.2015.03.002

Cameran, M. (2005). Audit Fees and the Large Auditor Premium in the Italian Market. International Journal of Auditing, 9, 129146. doi: 10.1111/j.1099-1123.2005.00205.x

Castro, W. B. d. L., Peleias, I. R., \& Silva, G. P. d. (2015). Determinan of Audit Fees: a Study in the Companies Listed on the BMEFBOVESPA Brazil. Paper presented at the AnPAD Meeting, Rio de Jeneiro.

Elhaj, M. A. A., Muhamed, N. A., \& Ramli, N. M. (2015). The Influence of Corporate Governance, Financial Ratio, and Sukuk Structure on Sukuk Rating. Procedia Economic and Finance, 31, 62-74. doi: doi: 10.1016/S2212-5671(15)01132-6

Fachrurrozie, T. N., \& Jayanto, P. Y. (2014). Pengaruh Rasio Keuangan Terhadap Rating Sukuk Dengan Manajemen Laba Sebagai Variabel Intervening. Accounting Analysis Journal, 3(1).

Fleischer, R., \& Goettsche, M. (2012). Size Effects and Audit Pricing: Evidence from Germany. Journal of International Accounting, Auditing, and Taxation, 21, 156-168. doi: http://dx.doi. org/10.1016/j.intaccaudtax.2012.07.005 
Ghozali, I. (2016). Aplikasi Analisis Multivariate dengan Program SPSS (Vol. 8). Semarang: Badan Penerbit Universitas Diponegoro.

Hanafi, M. M., \& Halim, A. (2014). Analisis Laporan Keuangan (Keempat ed.). Yogyakarta: UPP STIM YKPN.

Hassan, Y. M., \& Naser, K. (2013). Determinant of Audit Fees: Evidence from an Emerging Economy. International Business Research, 6.

Inchausti, B. G. (1997). The influence of company characteristics and accounting regulation on information disclosed by Spanish firms. European Accounting Review, 6(1), 45-68. doi: 10.1080/096381897336863

Indriantoro, N., \& Supomo, B. (2002). Metodologi Penelitian Bisnis untuk Akuntansi dan Manajemen (Pertama ed.): BPFE Yogyakarta.

Iqbal, Z., \& Mirakhor, A. (2011). An Introduction to Islamic Finance (Vol. 2). Singapore: John Wiley \& Sons (Asia) Pte. Ltd.

Melis, K. (2015). Analisis Faktor-Faktor yang Mempengaruhi Rating Sukuk. Jurnal Ilmiah Mahasiswa FEB Universitas Brawijaya, 3.

MUI. (2002). Fatwa Dewan Syari'ah Nasional Nomor 32/DSN-MUI/ IX/2002 Obligasi Syariah. Jakarta: Majelis Ulama Indonesia.

Naser, K., Al-Khatib, K., \& Karbhari, Y. (2002). EMPIRICAL EVIDENCE ON THE DEPTH OF CORPORATE INFORMATION DISCLOSURE IN DEVELOPING COUNTRIES: THE CASE OF JORDAN. International Journal of Commerce and Management, 12(3/4), 122-155. doi: doi:10.1108/eb047456

Naser, K., \& Hassan, Y. M. (2016). Factors Influencing External Audit Fee of Company Listed on Dubai Financial Market. International Journal of Islamic and Middle Eastern Finance and Managemen, 9(3). doi: http://dx.doi.org/10.1108/IMEFM01-2015-0007

Naser, K., \& Nuseibeh, R. (2008). Determinants of Audit Fees: Empirical Evidence From An Emerging Economy. International Journal of Commerce and Management, 17(3), 239 $-254$. 
Othman, R., Thani, A. M., \& Ghani, E. K. (2009). Determinan of Islamic Social Reporting Among Top Shariah-Approved Companies in Bursa Malaysia. Research Journal of International Studies(12).

Purwaningsih, S. (2013). Faktor yang Mempengaruhi Rating Sukuk yang Ditinjau dari Faktor Akuntansi dan Non Akuntansi. Accounting Analysis Journal, 2(3), 360-368.

Rouf, A. (2011). Corporate Characteristics, Governance Attributes and The Extent of Voluntary Disclosure in Bangladesh. African Journal of Business Management, 5(15), 7836-7845. doi: 10.5897/ AJBM10.1180

Rusmanto, T., \& Waworuntu, S. R. (2015). Factor Influencing Audit Fee In Indonesia Publicly Listed Companies Applying GCG. Procedia - Social and Behavioraal Sciences, 172, 63 - 67.

Sudaryanti, N., Mahfudz, A. A., \& Wulandari, R. (2011). Analisis Determinan Peringkat Sukuk dan Peringkat Obligasi di Indonesia. Islamic Finance \& Business Review, 6(2), 105-137.

ulHaq, A., \& Leghari, M. K. (2015). Determinants of Audit Fee in Pakistan. Research Journal of Financial and Accounting, 6(9), 176-188.

Vermeer, T. E., Raghunandan, K., \& Forgione, D. A. (2009). Audit Fees at U.S. Non-Profit Organizations. AUDITING: A Journal of Practice \& Theory, 28(2), 289-303. doi: 10.2308/ aud.2009.28.2.289

Younas, Z. I., Velte, P., \& Ashfaq, K. (2014). Audit Pricing in China and Pakistan: A Comparative Review of Audit Practices. Accounting and Manajemen Information System, 13(1), 98-110.

Zakaria, N. B., Isa, M. A. M., \& Abidin, R. A. Z. (2012). The Construct of Sukuk, Rating, and Default Risk. Procedia Economic and Finance, 65, 662-667. 
Wahyu Pramesti 